Supporting Information for

\title{
Standard Reduction Potentials for Oxygen and Carbon Dioxide Couples in Acetonitrile and $N, N$-Dimethylformamide
}

\author{
Michael L. Pegis,${ }^{\dagger}$ John A. S. Roberts, ${ }^{\ddagger}$, Derek J. Wasylenko,,$\|$ Elizabeth A. Mader, ${ }^{\dagger}$ \\ Aaron M. Appel,,$\stackrel{*}{*}$ and James M. Mayer ${ }^{*}, \dagger$ \\ $\dagger$ Department of Chemistry, Yale University, PO Box 208107, New Haven CT 06520-8107, United States \\ $¥$ Center for Molecular Electrocatalysis, Pacific Northwest National Laboratory, P.O. Box 999 (K2-57), Richland, \\ Washington 99352, United States. \\ \# Department of Chemistry, Campus Box 351700, University of Washington, Seattle, WA, 98195-1700, United \\ States. \\ $\S$ REC Silicon, 3322 Road "N" NE, Moses Lake, WA 98837, United States \\ " FireWater Fuel Corp., 3535 Research Road N.W., Calgary, AB, T2L 2K8, Canada \\ Contact: AMA: aaron.appel@pnnl.gov, JMM: james.mayer@yale.edu
}

\section{Table of Contents}

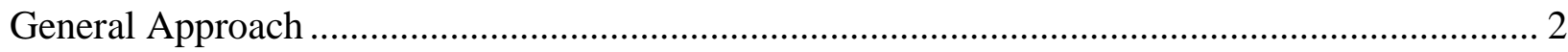

Experimental Details for Determining the $\mathrm{H}^{+} / \mathrm{H}_{2}$ Couple in DMF............................................. 4

Thermodynamic Schemes to Determine the $\mathrm{CO}_{2} / \mathrm{CO}$ and $\mathrm{CO}_{2} / \mathrm{CH}_{4}$ Couples.............................. 5

Using Vapor Pressure to Determine the Effects of Acid on Water in Organic Solvents................. 6 


\section{General Approach}

Our general approach for acquiring equilibrium potentials in non-aqueous media $(\mathrm{MeCN} \&$ DMF) relies on the equilibrium potential for $\mathrm{H}^{+} / \mathrm{H}_{2}$ in organic solvents (org) determined experimentally. The details of such electrochemical experiments are discussed in section 2 . The equilibrium potential for $\mathrm{O}_{2} / \mathrm{H}_{2} \mathrm{O}$ in aqueous medium can be used in combination with other thermochemical equations to acquire the thermodynamics for $\mathrm{O}_{2} / \mathrm{H}_{2} \mathrm{O}$ in non-aqueous solvents.

The conversion begins with the respective half reactions in aqueous media. ${ }^{1}$

$$
\begin{aligned}
& \mathrm{O}_{2(\mathrm{~g})}+4 \mathrm{H}^{+}{ }_{(\mathrm{aq})}+{\mathrm{e}^{-}}_{(\mathrm{SHE})}^{\stackrel{E^{\circ} \mathrm{O} 2 / \mathrm{H} 2 \mathrm{O}(\mathrm{aq})}{\rightleftharpoons}} 2 \mathrm{H}_{2} \mathrm{O}_{(\mathrm{aq})} \quad E^{\circ} \mathrm{O} / \mathrm{H} 2 \mathrm{O}(\mathrm{aq})=1.229 \mathrm{~V} \text { vs NHE } \\
& 2 \mathrm{H}_{2(\mathrm{~g})} \stackrel{-E^{\circ}{ }^{\circ}+/ \mathrm{H} 2(\mathrm{aq})}{\rightleftharpoons} 4 \mathrm{H}_{(\mathrm{aq})}^{+}+{e^{-}}_{(\mathrm{SHE})} \quad-E^{\circ}{ }_{\mathrm{H}+/ \mathrm{H} 2(\mathrm{aq})}=0 \mathrm{~V} \text { vs NHE } \\
& \mathrm{O}_{2(\mathrm{~g})}+2 \mathrm{H}_{2(\mathrm{~g})} \rightleftharpoons 2 \mathrm{H}_{2} \mathrm{O}_{(\mathrm{aq})} \quad E^{\circ}=1.229 \mathrm{~V} \text { vs NHE } \\
& \Delta G^{\circ}{ }_{\mathrm{O} 2 / \mathrm{H} 2 \mathrm{O}}=-n F E_{\text {cell }}^{\circ}=-(4)\left(23.06 \mathrm{kcal} \mathrm{mol}^{-1} \mathrm{~V}^{-1}\right)(1.229 \mathrm{~V})=-113.4 \mathrm{kcal} / \mathrm{mol}
\end{aligned}
$$

This yields the free energy for production of two molecules of water from oxygen and hydrogen in their standard state.

Next, the thermodynamic potential for the $\mathrm{H}^{+} / \mathrm{H}_{2}$ half reaction in organic solvent can be used (see the experimental details section below). For the sake of clarity, we will assume org $=\mathrm{MeCN}$.

$$
\begin{aligned}
& \left.4 \mathrm{H}^{+}{ }_{(\mathrm{org})}+4{e^{-}}_{\left(\mathrm{Fc}^{+/ 0}\right)} \stackrel{E^{\circ}{ }_{\mathrm{H}+/ \mathrm{H} 2(\mathrm{org})}}{=} 2 \mathrm{H}_{2(\mathrm{~g})} \quad E^{\circ}{ }_{\mathrm{H}+/ \mathrm{H} 2(\mathrm{org})}=-0.028 \mathrm{~V} \mathrm{vs} \mathrm{Fc}^{+/ 0} \text { (org }=\mathrm{MeCN}\right) \\
& 2 \times \Delta G^{\circ}{ }_{H+/ H 2(o r g)}=-n F E^{\circ}=-(4)\left(23.06 \mathrm{kcal} \mathrm{mol}^{-1} \mathrm{~V}^{-1}\right)(-0.028 \mathrm{~V})=2.6 \mathrm{kcal} / \mathrm{mol}
\end{aligned}
$$

$\mathrm{Fc}^{+/ 0}$ represents the ferrocenium/ferrocene couple, the preferred electrochemical standard in organic solvents. ${ }^{2}$ Finally, the free energy for transfer of $\mathrm{H}_{2} \mathrm{O}$ from (aq) to (org) must be considered. This is a minor contribution to the overall thermodynamics.

$$
2 \mathrm{H}_{2} \mathrm{O}_{(\mathrm{aq})} \stackrel{2 \times \Delta G^{\circ}{ }_{\mathrm{H} 2 \mathrm{O}(\mathrm{aq}->\mathrm{org})}^{\rightleftharpoons}}{\rightleftharpoons} 2 \mathrm{H}_{2} \mathrm{O}_{(\mathrm{org})} \quad 2 \times \Delta G^{\circ}{ }_{\mathrm{H} 2 \mathrm{O}(\mathrm{aq}->\mathrm{org})}=-0.9 \mathrm{kcal} / \mathrm{mol}(\mathrm{org}=\mathrm{MeCN})
$$

The summation of the equations above yields the free energy for $\mathrm{O}_{2} / \mathrm{H}_{2} \mathrm{O}$ in acetonitrile. Since the $\mathrm{H}^{+} / \mathrm{H}_{2}$ reaction is a half reaction referenced to ferrocene in acetonitrile, summation of the free energies above and conversion back to potential via the Nernst equation yields a potential referenced to ferrocene.

(1) S. G. Bratsch, J. Phys. Chem. Ref. Data, 1989, 18, 1-21.

(2) (a) R. R. Gagne, C. A. Koval, G. C. Lisensky, Inorg. Chem., 1980, 19, 2854-2855. (b) G. Gritzner, J. Kůta, Pure Appl. Chem. 1984, 56, 461-466. 


$$
\begin{aligned}
& \mathrm{O}_{2}(\mathrm{~g})+2 \mathrm{H}_{2}(\mathrm{~g}) \rightleftharpoons \mathrm{G}_{\mathrm{O} 2 / \mathrm{H} 2 \mathrm{O}(\mathrm{aq})}^{\mathrm{o}} \rightleftharpoons \mathrm{H}_{2} \mathrm{O}(\mathrm{aq}) \quad \Delta \mathrm{G}_{\mathrm{O} 2 / \mathrm{H} 2 \mathrm{O}(\mathrm{aq})}^{\mathrm{o}}=-113.4 \mathrm{kcal} / \mathrm{mol} \\
& 4 \mathrm{H}^{+}(\text {org })+4 \mathrm{e}^{-} \rightleftharpoons \mathrm{G}_{4 \mathrm{H}+/ 2 \mathrm{H} 2 \text { (org) }}^{\mathrm{o}} 2 \mathrm{H}_{2}(\mathrm{~g}) \quad \Delta \mathrm{G}_{4 \mathrm{H}+/ 2 \mathrm{H} 2 \text { (org) }}^{\mathrm{o}}=2.6 \mathrm{kcal} / \mathrm{mol}(\text { org }=\mathrm{MeCN})
\end{aligned}
$$

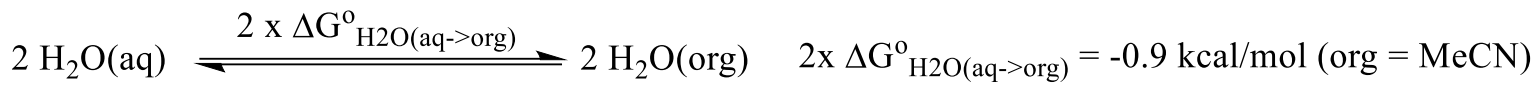

$$
\begin{aligned}
& \mathrm{O}_{2}(\mathrm{~g})+4 \mathrm{H}^{+} \text {(org) }+4 \mathrm{e}^{-} \rightleftharpoons 2 \mathrm{H}_{2} \mathrm{O} \text { (org) } \Delta \mathrm{G}_{\mathrm{O} 2 / \mathrm{H} 2 \mathrm{O}(\text { org })}^{\mathrm{o}}=-111.7 \mathrm{kcal} / \mathrm{mol}(\text { org }=\mathrm{MeCN}) \\
& E_{02 / \mathrm{H} 2 \mathrm{O}(\mathrm{org})}^{\mathrm{o}}=1.21 \mathrm{~V} \mathrm{vs} \mathrm{Fc}^{+/ 0}(\mathrm{org}=\mathrm{MeCN})
\end{aligned}
$$

The transfer free energy of $\mathrm{H}^{+}$aq->org can also be calculated using the scheme shown below.

$$
\begin{aligned}
& \mathrm{H}^{+}(\mathrm{aq})+\mathrm{e}^{-}(\mathrm{SHE}) \stackrel{\Delta \mathrm{G}_{\mathrm{H}+/ \mathrm{H} 2(\mathrm{aq})}^{\mathrm{o}}}{\rightleftharpoons} 1 / 2 \mathrm{H}_{2}(\mathrm{~g}) \quad \Delta \mathrm{G}_{\mathrm{H}+/ \mathrm{H} 2(\mathrm{aq})}^{\mathrm{O}}=0 \mathrm{kcal} / \mathrm{mol} \\
& 1 / 2 \mathrm{H}_{2}(\mathrm{~g}) \stackrel{-\Delta \mathrm{G}_{\mathrm{H}+/ \mathrm{H} 2 \text { (org) }}}{\rightleftharpoons} \mathrm{H}^{+}(\text {org })+\mathrm{e}^{-}\left(\mathrm{Fc}^{+/ \mathrm{o}}\right) \quad-\Delta \mathrm{G}_{\mathrm{H}+/ \mathrm{H} 2 \text { (org) }}^{\mathrm{o}}=-0.65 \mathrm{kcal} / \mathrm{mol}(\text { org }=\mathrm{MeCN}) \\
& \mathrm{e}^{-}\left(\mathrm{Fc}^{+/ 0}\right) \rightleftharpoons \mathrm{e}^{-}(\mathrm{SHE}) \quad-\Delta \mathrm{G}_{\mathrm{Fc} \text { vs SHE }}^{\mathrm{o}}=14.76 \mathrm{kcal} / \mathrm{mol} \\
& \Delta \mathbf{G}_{\mathrm{H}+(\mathrm{aq}->\mathrm{org})}^{\mathrm{o}}=14.1 \mathrm{kcal} / \mathrm{mol}(\mathrm{org}=\mathrm{MeCN})
\end{aligned}
$$




\section{Experimental Details for Determining the $\mathrm{H}^{+} / \mathrm{H}_{2}$ Couple in DMF}

To determine the potential of the $\mathrm{H}^{+}(\mathrm{DMF}) / \mathrm{H}_{2(\mathrm{~g})}$ couple in DMF, the previously reported general approach was used. ${ }^{3}$ The reported approach is based on measuring the open circuit potential of a platinum wire versus the ferrocenium/ferrocene couple $\left(\mathrm{Fc}^{+/ 0}\right)$. Instead of using a weak acid with a known $\mathrm{p} K_{\mathrm{a}}$ value, protonated $\mathrm{DMF}$ was added as the triflate salt, ${ }^{4}$ in effect equivalent to using triflic acid in DMF. The concentration dependence of the open circuit potential was used to extrapolate from the linear region to $1 \mathrm{M}$ solvated $\mathrm{H}^{+}$, yielding a potential of $-0.662 \mathrm{~V} \mathrm{vs}$. $\mathrm{Fc}^{+/ 0}$ in DMF, as illustrated in Figure S1, reproduced from Figure 1 from the main text for convenience.

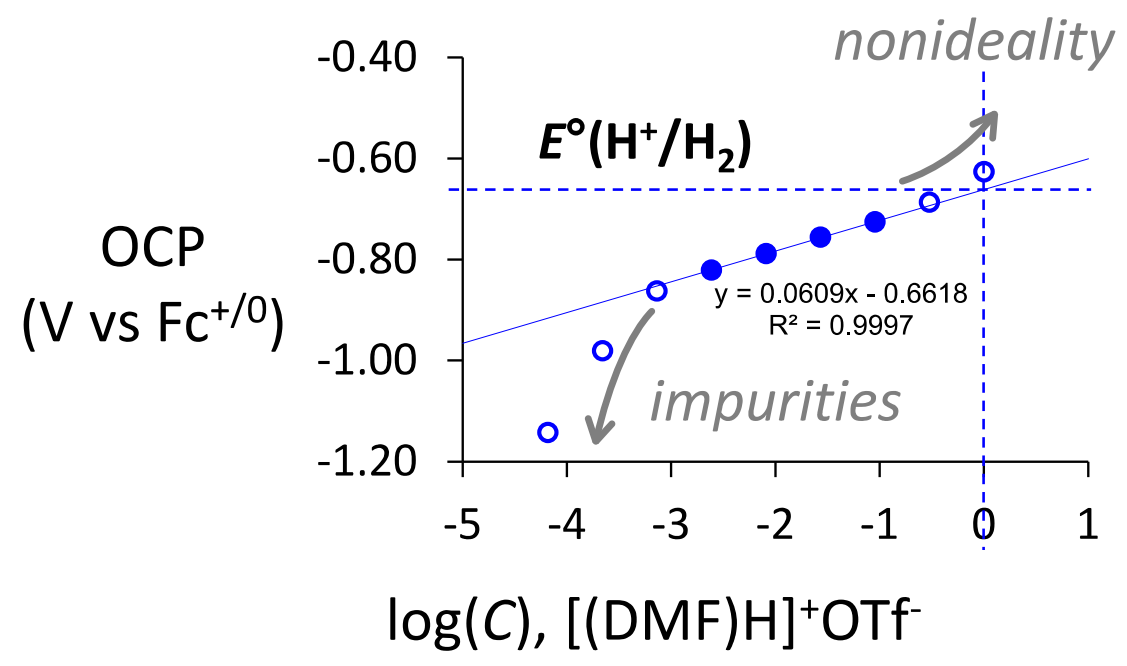

Figure S1 The potential for the $\mathrm{H}^{+} / \mathrm{H}_{2}$ couple in DMF based on the open circuit potential as a function of the concentration of $[(\mathrm{DMF}) \mathrm{H}]^{+} \mathrm{OTf}^{-}$, using the general procedure reported by Roberts and Bullock. ${ }^{3}$

(3) J. A. S. Roberts and R. M. Bullock, Inorg. Chem., 2013, 52, 3823-3835.

(4) I. Favier and E. Duñach, Tetrahedron Lett., 2004, 45, 3393-3395. 


\section{Thermodynamic Schemes to Determine the $\mathrm{CO}_{2} / \mathrm{CO}$ and $\mathrm{CO}_{2} / \mathrm{CH}_{4}$ Couples}

Scheme S1 Thermodynamic cycle for determining the $\mathrm{CO}_{2}$ to $\mathrm{CO}$ reduction potentials in $\mathrm{MeCN}$ and DMF using the analogous approach to that for $\mathrm{O}_{2}$ to $\mathrm{H}_{2} \mathrm{O}$.

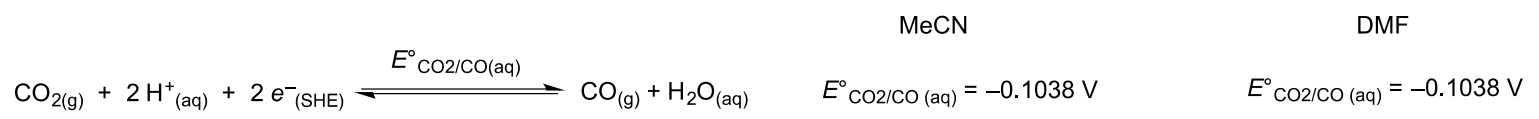

$$
\begin{aligned}
& \mathrm{H}_{2(\mathrm{~g})} \stackrel{-E_{\mathrm{H}+(\mathrm{aq}) / \mathrm{H} 2}}{\longrightarrow} 2 \mathrm{H}^{+}{ }_{(\mathrm{aq})}+2 \mathrm{e}^{-}(\mathrm{SHE}) \quad-E_{\mathrm{H}+(\mathrm{aq}) / \mathrm{H} 2}^{0}=0 \mathrm{~V} \quad-E_{\mathrm{H}+(\mathrm{aq}) / \mathrm{H} 2}^{\circ}=0 \mathrm{~V}
\end{aligned}
$$

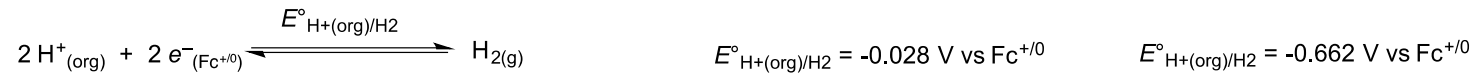

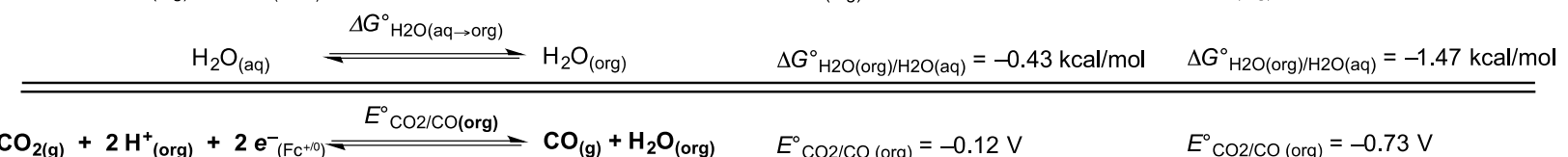

Scheme S2 Thermodynamic cycle for determining the $\mathrm{CO}_{2}$ to $\mathrm{CH}_{4}$ reduction potentials in

\begin{tabular}{|c|c|c|c|c|}
\hline & & & $\mathrm{MeCN}$ & DMF \\
\hline $\mathrm{CO}_{2(\mathrm{~g})}+8 \mathrm{H}^{+}{ }_{(\mathrm{aq})}+8 \mathrm{e}^{-}(\mathrm{SHE})^{-}$ & $E_{\mathrm{CO} 2 / \mathrm{CH} 4(\mathrm{aq})}^{\circ}$ & $\mathrm{CH}_{4(\mathrm{~g})}+2 \mathrm{H}_{2} \mathrm{O}_{(\mathrm{aq})}$ & $E^{\circ} \mathrm{CO} 2 / \mathrm{CH}_{4}(\mathrm{aq})=+0.169 \mathrm{~V}$ & $E_{\mathrm{CO} / \mathrm{CH} 4(\mathrm{aq})}^{\circ}=+0.169 \mathrm{~V}$ \\
\hline $4 \mathrm{H}_{2(\mathrm{~g})}$ & $-E_{\mathrm{H}+(\mathrm{aq}) / \mathrm{H} 2}^{\mathrm{N}}$ & $8 \mathrm{H}^{+}{ }_{(\mathrm{aq})}+8 \mathrm{e}^{-}(\mathrm{SHE})$ & $-E_{\mathrm{H}+(\mathrm{aq}) / \mathrm{H} 2}=0 \mathrm{~V}$ & $-E_{\mathrm{H}+(\mathrm{aq}) / \mathrm{H} 2}^{0}=0 \mathrm{~V}$ \\
\hline $8 \mathrm{H}^{+}($org $)+$ & $E^{\circ} \mathrm{H+( \text {org } ) / \mathrm { H } 2}$ & $4 \mathrm{H}_{2(\mathrm{~g})}$ & $E_{\mathrm{H}+(\mathrm{org} / / \mathrm{H} 2}^{\circ}=-0.028 \mathrm{Vvs} \mathrm{Fc}^{+/ 0}$ & 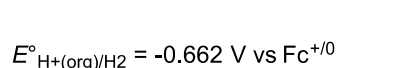 \\
\hline $2 \mathrm{H}_{2} \mathrm{O}_{(\mathrm{aq})}$ & $\stackrel{\Delta G^{\circ}{ }^{H} 2 \mathrm{O}(\mathrm{aq} \rightarrow \mathrm{org})}{\longrightarrow}$ & $2 \mathrm{H}_{2} \mathrm{O}_{\text {(org) }}$ & $2 \Delta G^{\circ}{ }_{\mathrm{H} 2 \mathrm{O}(\mathrm{org}) / \mathrm{H} 2 \mathrm{O}(\mathrm{ag})}=-0.86 \mathrm{kcal} / \mathrm{mol}$ & 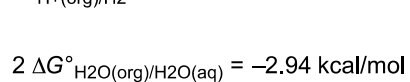 \\
\hline$H^{\prime}$ (org) & $E_{\mathrm{CO} 2 / \mathrm{CH} 4 \text { (org) }}^{\circ}$ & $\mathrm{H}_{2} \mathrm{O}_{\text {(org) }}$ & $E_{\mathrm{CO} / \mathrm{CH} 4(\mathrm{org})}^{\circ}=+0.15 \mathrm{~V}$ & $E^{\circ} \mathrm{CO} / \mathrm{CH} 4$ (org) $=-0.48 \mathrm{~V}$ \\
\hline
\end{tabular}
$\mathrm{MeCN}$ and DMF using the analogous approach to that for $\mathrm{O}_{2}$ to $\mathrm{H}_{2} \mathrm{O}$. 


\section{Using Vapor Pressure to Determine the Effects of Acid on Water in Organic Solvents}

(A) To determine the effect of acid upon the transfer free energy of water into organic solvents, the vapor pressure of water in $\mathrm{MeCN}$ was examined using gas phase IR spectroscopy by monitoring the change in intensity of $\mathrm{H}_{2} \mathrm{O}$ absorption modes in the $3600-4000 \mathrm{~cm}^{-1}$ region. These experiments were acquired in transmission mode on a Bruker alpha IR spectrometer inside an $\mathrm{N}_{2}$ atmosphere glovebox using an $8 \mathrm{~cm}$ path length quartz cell.

A $20 \mathrm{~mL}$ solution of $1 \mathrm{M} \mathrm{H}_{2} \mathrm{O}$ in $\mathrm{MeCN}$ was prepared by combining 'dry' MeCN (19.64 $\mathrm{mL})$ with $\mathrm{H}_{2} \mathrm{O}(360 \mu \mathrm{L}) .1 \mathrm{~mL}$ of this solution was added to the solution reservoir of the quartz cell and sealed. An IR spectrum was then collected (Figure S2). The absorption intensity did not change over the course of 18 hours, confirming the cell had fully equilibrated. The temperature inside the spectrometer remained constant at $25^{\circ} \mathrm{C}$.

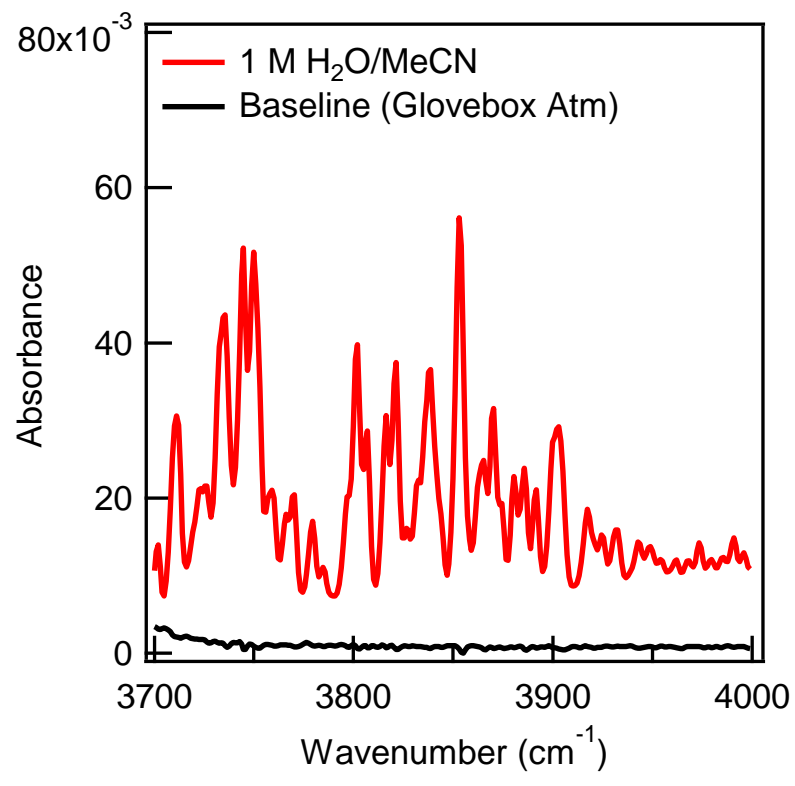

Figure S2 Gas phase IR spectrum of $1 \mathrm{M} \mathrm{H}_{2} \mathrm{O}$ dissolved in $\mathrm{MeCN}$, where "Baseline (Glovebox Atm)" represents the spectrum taken in an empty quartz cell open to the glovebox atmosphere. 
(B) The cell was removed from the glove box, cleaned, and dried under an $\mathrm{N}_{2}$ stream. [HDMF]OTf or HOTf was added to aliquots of the $1 \mathrm{M} \mathrm{H}_{2} \mathrm{O} / \mathrm{MeCN}$ stock solution to produce solutions containing $1 \mathrm{M}[(\mathrm{DMF}) \mathrm{H}]^{+} \mathrm{OTf}^{-}$and $1 \mathrm{M}^{\mathrm{HOTf}}$. These solutions will be referred to as 1 $\mathrm{M}[(\mathrm{DMF}) \mathrm{H}]^{+} \mathrm{OTf}^{-} / 1 \mathrm{M} \mathrm{H}_{2} \mathrm{O} / \mathrm{MeCN}$ and $1 \mathrm{M} \mathrm{HOTf} / 1 \mathrm{M} \mathrm{H}_{2} \mathrm{O} / \mathrm{MeCN}$ respectively.

The gas phase IR spectra for these solutions has a significant attenuation of water vapor absorption $(\approx 10$-fold decrease in absorption, Figure S3).

$1 \mathrm{M} \mathrm{DMF}$ was then added to the $1 \mathrm{M}[(\mathrm{DMF}) \mathrm{H}]^{+} \mathrm{OTf}^{-} / 1 \mathrm{M} \mathrm{H}_{2} \mathrm{O} / \mathrm{MeCN}$ solution (Figure $\mathrm{S} 4)$. The water absorption increased to nearly half the original intensity.

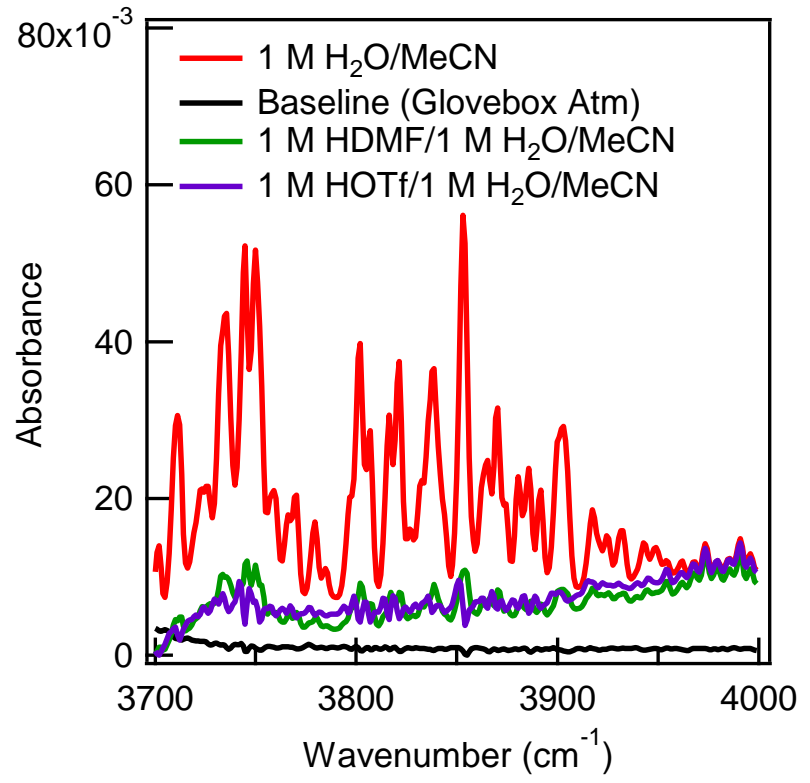

Figure S3 Gas phase IR spectrum of $1 \mathrm{M} \mathrm{H}_{2} \mathrm{O}$ dissolved in MeCN upon addition of acids.

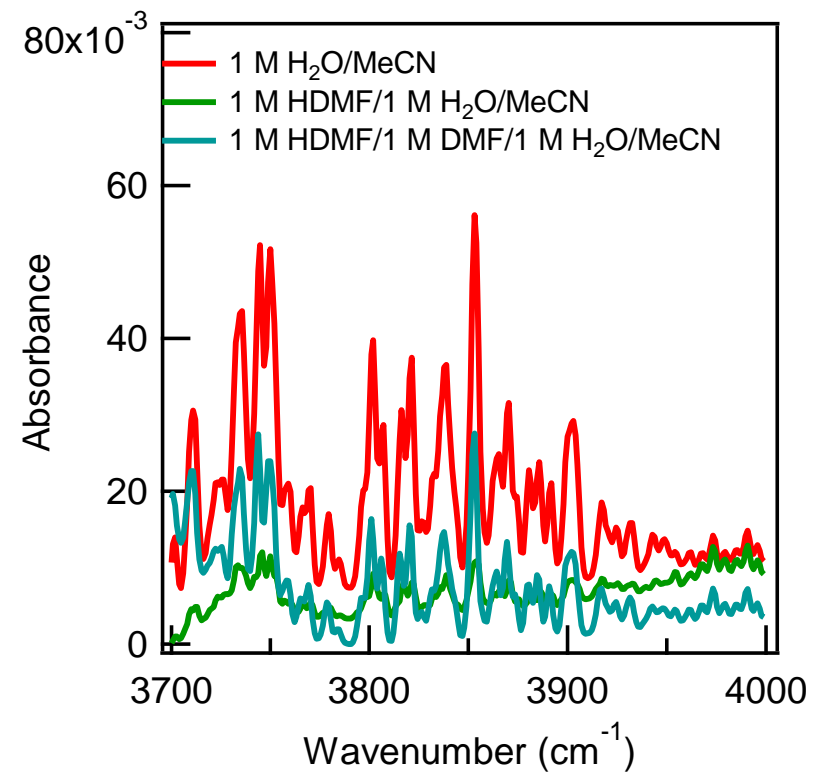

Figure S4 Gas phase IR spectrum of $1 \mathrm{M}$ $\mathrm{H}_{2} \mathrm{O}$ dissolved in $\mathrm{MeCN}$ in the presence of $1 \mathrm{M}[(\mathrm{DMF}) \mathrm{H}]^{+} \mathrm{OTf}^{-}$and $1 \mathrm{M}$

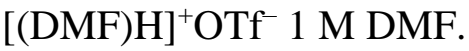


(C) Similar experiments have been done using a higher resolution IR spectrometer outside of the glovebox, shown in Figure S5. Overall, these experiments suggest the vapor pressure of $\mathrm{H}_{2} \mathrm{O}$ over MeCN can change by 2-10 fold upon addition of acid, resulting in an error in the $\mathrm{O}_{2} /$ $\mathrm{H}_{2} \mathrm{O}_{\text {(solv) }}$ couple of 9-30 mV.

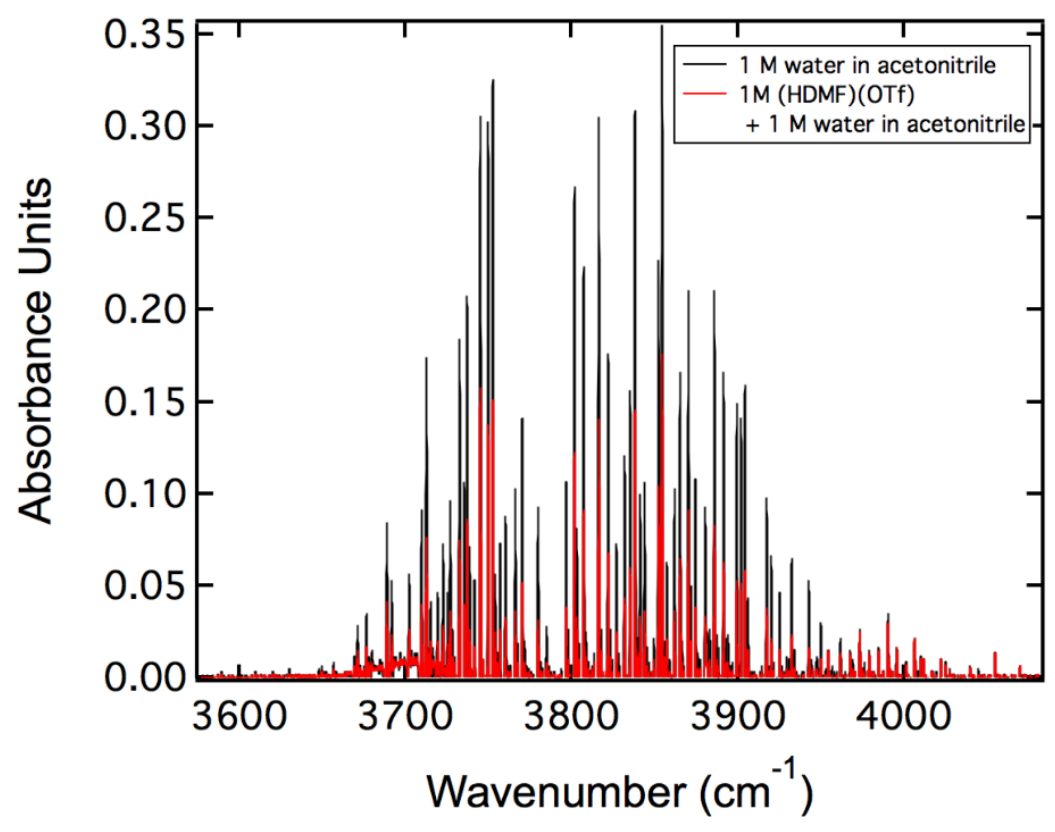

Figure S5 Gas phase IR experiments of $1 \mathrm{M} \mathrm{H}_{2} \mathrm{O}$ dissolved in acetonitrile. 